\title{
Komunikacja społeczna a standard wielokulturowości. Hybrydalne artefakty w kulturze
}

\begin{abstract}
STRESZCZENIE
Komunikowanie się jako proces wymaga odwołania się do przestrzeni komunikacji społecznej, którą rozumiem jako założenia sensu symboli komunikacyjnych. Hybrydalność jako zjawisko w kulturze jest z jednej strony faktem społecznym, efektem procesów globalizacyjnych, z drugiej staje się wyzwaniem w procesie narracji edukacyjnej. Zachowanie ciągłości i spójności w kulturze w obliczu problemu hybrydalności i zbudowanie komunikacji zdolnej podjąć to wyzwanie wydaje się być ważnym namysłem także (a może przede wszystkim) w dziedzinie pedagogiki. Wielokulturowość jako idea, o ile miałaby stać się zasadą społeczną, wymaga debaty kompetentnych rozmówców. Stąd wynika potrzeba namysłu nad kompetencją komunikacyjną jednostek standardu wielokulturowości.
\end{abstract}

\section{Słowa kluczowe:}

wielokulturowość, komunikacja, przekaz pedagogiczny, hybrydalność

\section{ABSTRACT}

Communicating as a process requires referring to the space of social communication, which I understand as the assumptions of the sense of communication symbols. Hybridity as a phenomenon in culture is on one hand a social fact, the effect of globalization processes, on the other it becomes

1 Dorota Misiejuk, Wydział Pedagogiki i Psychologii, Uniwersytet w Białymstoku, Polska, dmisiejuk@uwb.edu.pl. 
a challenge in the process of educational narrative. Maintaining continuity and cohesion in culture in the face of the problem of hybridity and building communication capable of taking up this challenge seems to be an important consideration also (and perhaps above all) in the field of pedagogy. Multiculturalism as an idea, if it were to become a social principle, requires a debate of competent interlocutors. Hence the need to reflect on the communicative competence of the units of the multiculturalism standard.

\section{Keywords:}

multiculturalism, communication, pedagogical message, hybridity

\section{WPROWADZENIE}

Komunikowanie się jako proces wymaga odwołania się do przestrzeni komunikacji społecznej, którą rozumiem jako założenia sensu symboli komunikacyjnych. Tym samym, artefakty w kulturze działają w polu tradycji [określonej kultury]. Proces komunikowania się staje się sensowny, kiedy odnosimy go do istniejących [w kulturze] stałych: systemów wartościowania (intencji) i istniejących w kulturze relacji. Pierwszy odnosi się do treści artefaktu kultury i reguluje moc komunikatu, kiedy drugi reguluje interakcją, odnosi się do tożsamości mówiących. Hybrydalne artefakty w kulturze to zjawisko ery globalizacji oraz historycznie ujęte doświadczenie pogranicza. To sytuacja komunikacyjna, kiedy tradycja jako układ orientujący rozmówców zostaje oprotestowana bądź zmienia się. Ulegają dyslokacji orientujące stałe: wartościowanie (rozumiane jako lokowanie artefaktu na kontinuum sacrum-profanum) oraz relacje. Interakcja jest tym samym zawieszona w próżni znaczeniowej.

Sytuacja ta jest w kulturze oznaką zmian, przewartościowań; w edukacji jest sytuacją trudną. Edukacja jako system w kulturze jest odpowiedzialna za wprowadzanie w świat znaczeń młode pokolenie. Wprowadzanie to nie powinno się odbywać poza realnymi uwarunkowaniami społeczno-kulturowymi. Trudność polega na tym, że przekazując sensy opieramy się na artefaktach kultury, a te mają moc przekazu pod warunkiem odniesienia ich do określonej tradycji. Tylko wtedy budują ludzkie nastawienia do świata. Poza tradycją ich znaczenie jest nieokreślone i dopuszczane są wszelkie interpretacje. W konsekwencji pole wartości, którym zarządza określony artefakt jest nieoznaczone, co oznacza, że społecznie jest bezużyteczne. Nie kształtuje ludzkich nastawień do świata. 


\section{SENS SYMBOLI KOMUNIKACYJNYCH W STANDARDZIE WIELOKULTUROWYM}

Standardem społeczno-kulturowym ery ponowoczesności staje się wielokulturowość. Wielokulturowość społeczeństw będzie taka, jakie uzgodnimy znaczenie pojęcia. Definicyjne spory nad nim mają już w tradycji polskiego piśmiennictwa długą historię. Istnieją definicje deskryptywne, opisujące wielokulturowość jako efekt migracji oraz emancypacji mniejszości. Przykładem tego podejścia może być definicja Mariana Golki. Wielokulturowość opisuje on jako fakt występowania obok siebie różnych społeczności kulturowych, które aspirują jednocześnie do zaistnienia w tej samej przestrzeni. Konstruują wzajemnie postrzeganie odmienności z różnymi skutkami (Kempny, Łapciak, Łodziński, 1997, s. 64). Znajdziemy w literaturze także stanowiska tłumaczące wielokulturowość jako świadomą reakcję na efekt pluralizmu kulturowego w państwie. Wtedy pojęcie to interpretowane jest normatywnie przez postawy: szacunku, uznania, emancypacji, równych praw społecznych niezależnie od przynależności kulturowej. Takie stanowisko w swoich pracach deklarują Joanna Kurczewska, Jerzy Nikitorowicz, Andrzej Sadowski ${ }^{2}$. W tych definicjach z reguły przywoływana jest zasada demokracji jako zasada konstruująca wspólnotę ponad kulturowymi podziałami: „zasada demokratycznego współistnienia jednostek i grup powołujących się na swoją szczególna tożsamość kulturową” (Kempny, Łapciak, Łodziński, 1997, s. 49). Andrzej Sadowski w swoim tekście Wielokulturowość jako czynnik zrównoważonego i inteligentnego rozwoju Polski podkreśla, że: „z fenomenem wielokulturowości mamy do czynienia wówczas, gdy dochodzi do trwałych, wielopłaszczyznowych i dobrowolnych kontaktów międzykulturowych, które powodują wytworzenie się całości nowej i kulturowo zróżnicowanej” (Sadowski, 2016, s. 7). Zwraca uwagę, że idzie tutaj o fundamentalne podkreślenie wolności jednostki do czerpania z dowolnej tradycji i nieuprawnione jest zaprzeczanie prawom społecznym jednostek z powodu odniesień do innych niż tradycja większości. Budowanie tego standardu ${ }^{3}$ nie jest zadaniem jednostek i nie kształtuje się w czasie krótkim.

2 Zob. Kurczewska J., Kanon kultury narodowej. W: Kultura narodowa i polityka. Warszawa 2000; Nikitorowicz J., Edukacja regionalna i międzykulturowa. Warszawa 2009; Sadowski A., Od eksplozji do realnych zagrożeń idei i praktyk wielokulturowości: potrzeba nowych koncepcji i badań. W: Społeczeństwo wielokulturowe nowe wyzwania i zagrożenia. Biernacka M., Krzysztofik K., Sadowski A. (red.), Białystok 2012;

3 Koncepcja standardu kulturowego, na której Autorka opiera swoje rozważania, opisana jest w pracy: Brozi K.J., Antropologia wartości. Kategoria standardu kulturowego w badaniach nad wartościami. Lublin 1994. Omówienia tej koncepcji znajdzie też czytelnik w pracach: Radomski 
To proces kulturowy - a więc proces długiego trwania. Niemniej dzieje się mocą wolności jednostki i jej uwięzienia w kulturze $e^{4}$. Oprócz tego, że to proces długiego trwania i jego efekt obserwujemy w pokoleniowej zmianie, dzieje się w aktach komunikowania się. Jego dynamika, sensowność, a w ostateczności efekt w postaci zmiany kulturowej zależy od poziomu samoświadomości jednostek uczestniczących w akcie przenoszenia znaczeń, ich kompetencji czytania symboli oraz nastawień światopoglądowych. W związku z tym, rozpatrując przygotowywanie wychowanków do standardu wielokulturowości, uwagę winniśmy skupić na potencjale samoświadomości uczniów, budowaniu kompetencji w zakresie czytania symboli oraz rozumienia wagi nastawień światopoglądowych. Jak twierdzi filozof Chantal Delsol, zmiana, aby była sensowna, nie może się dokonać bez samowiedzy i znajomości własnych fundamentów, przez co rozumie świadomość motywów, czyli sferę etyczną działań w kulturze osadzoną w tradycji. Autorka woła o potrzebę oparcia zmian w kulturze na głębokiej refleksji. Jak pisze: „tego nie robi się z kaprysu i na podstawie subiektywnego sądu. Zmiana następuje w oparciu o refleksję dotyczącą swoich granic” (Delsol, 2018, s. 34). Proces uświadamiania owych granic daje się opisać w perspektywie zaplecza kulturowego i tożsamości. Zaplecze kulturowe to - z perspektywy jednostki - nasze obowiązki w stosunku do świata kulturowego. Świat kulturowy egzemplifikowany jest poprzez zasady, do których jesteśmy przywiązani prawie bezwiednie. Jak pisze cytowana już Chantal Delsol: „zasada, z definicji pierwotna, to coś, co nie opiera się na niczym, ale na czym wszystko się opiera, przynajmniej w przypadku konkretnej kultury” (Delsol, 2018, s. 7) i dalej „tych podstawowych zasad nie da się uprawomocnić na drodze rozumowania” (Delsol, 2018, s. 8). Zaplecze kulturowe formatowane jest na gruncie religii i tradycji. Jak pisze Autorka: „Tam, gdzie zanika wiara religijna, pozostaje tradycja. Tam, gdzie wiara odwołuje się do historii świętej, do prawdy, także do rozumu, zwykła tradycja odwołuje się do życia społeczeństw w perspektywie długiego trwania, które to życie ukształtowało ludzi w taki lub inny sposób, przyzwyczajając ich do uznawania pewnych zasad” (Delsol, 2018, s. 28). Prawa, zwyczaje, zakazy zawsze są wyrazem pewnej wizji człowieka. W perspektywie długiego trwania idzie tutaj o ustalenie tego, jakie reguły interpretacji zachowań innych ludzi, jakie kody do materialnych artefaktów kultury będziemy stosować

A., Antropologia jako nauka. Krzysztofa Broziego koncepcja standardu kulturowego w badaniach kulturoznawczych. Pobrane z: https://depot.ceon.pl; Misiejuk D., Inność w kontekście imigracji ogląd światopoglądu studentów. Studium interpretacyjne w świetle teorii standardu kulturowego K.J. Brozi.Multicultural Studies, 2, 2017.

4 Przywołana tutaj relacja człowiek-kultura analizowana jest w pracach: Linton R., Kulturowe podstawy osobowości. Warszawa 2000; Nowicka E., Świat człowieka, świat kultury. Warszawa 2000. 
jako nowe jakościowo, zachodnie społeczeństwo późnej nowoczesności. „Zdajemy już sobie sprawę, że wizja człowieka organizująca pewną kulturę nie jest przedmiotem nauki, ale wiary. Antropologii nie poznajemy, lecz ją wybieramy, nie pod wpływem kaprysu, lecz zgodnie z wieloma wymogami kultury, do której konkretna antropologia należy” (Delsol, 2018, s. 82).

Tożsamość kulturowa jako kategoria pojęciowa w naukach społecznych doczekała się także wielu interpretacji. W perspektywie szerokiej, zaprezentowanej w książce Tadeusza Palecznego pt. Socjologia tożsamości, autor pokazuje tożsamość jako rezultat klasyfikacji świata społecznego, porządek zaprowadzony w świecie ludzkich grup, zbiorowości, wspólnot. Twierdzi, że pojęcie to nazywa system symboliczny, wokół którego organizują się zbiorowości kulturowe. Jest obrazem grupy z cechami wyróżniającymi ją od innych i łączącymi jednostki w grupie. Obraz ten może być prezentowany w różnych porządkach: systemu wartościowania przyjętego w danej wspólnocie, obyczajów i postaw wyrażających te wartości oraz artefaktów kulturowych ilustrujących dwa poprzednie porządki. Funkcjonalność tej kategorii zapewnia jednostkom poczucie bezpieczeństwa, daje pozór życia w znanym i zrozumiałym terenie, którego zaburzenie wywołuje lęk i utratę zdolności orientowania się w społecznym środowisku. Pozwala przewidywać, wchodzić w interakcje zarówno w wymiarze komunikowania się, jak i w wymiarze metafizycznym - z ideami. Koncepcja tożsamości kulturowej zakłada przede wszystkim sens, orientuje jednostkę na znaczenie. Ludzie myślą i działają w odniesieniu do świata zgodnie z jego modelem symbolicznym, a nie z „obiektywną” istotą świata. W pedagogice tożsamość kulturowa doczekała się wielu opisów. Podejmowano badania w różnych modelach metodologicznych i w oparciu o różnorodne koncepcje. Wiele do dyskusji o tożsamości kulturowej wnoszą prace publikowane w ramach działalności Społecznego Zespołu Badań Kultury i Oświaty Pogranicza ${ }^{5}$, powstało też wiele prac autorskich ${ }^{6}$. W obecnych czasach badacze problemu zwracają uwagę na cechę tożsamości, którą określają jako płynność oraz podkreślają zmianę, jaka zaszła w kulturze i modelu tożsamości.

5 Społeczny Zespół Badań Kultury i Oświaty Pogranicza, funkcjonuje od 1994 r. i do tej pory wydał wiele publikacji z zakresu badania tożsamości kulturowej.

${ }^{6}$ Zob. Sobecki M., Kultura symboliczna a tożsamość. Białystok 2007; Machaj I., Społeczno-kulturowe konteksty tożsamości mieszkańców wschodniego i zachodniego pogranicza Polski. Warszawa 2005; Grabowska B., Poczucie tożsamości młodzieży uczq̨cej się w szkołach z polskim językiem nauczania na Białorusi, Ukrainie i w Republice Czeskiej - studium porównawcze. Toruń 2013; Szczurek-Boruta A., Zadania rozwojowe młodzieży i edukacyjne warunki ich wypełniania w środowiskach zróżnicowanych kulturowo i gospodarczo. Katowice 2007; Misiejuk D., Dziedzictwo i dziedziczenie w kontekście procesów socjalizacji. Białystok 2013. 
Tożsamość kulturowa w nowoczesnym układzie kultury nie jest efektem dziedziczenia, a wyzwaniem egzystencjalnym. W kulturze zakwestionowano odwieczną mechanikę tożsamości, o jakiej piszą Tomasz Szkudlarek i Zbyszko Melosik: „W przeszłości każda epoka, każde społeczeństwo miało swój dominujący typ tożsamości, sposób tworzenia «ja» i jego społecznych interakcji, który w trakcie praktyk społecznych był normalizowany, podnoszony do rangi «uniwersalnej». On to stawał się punktem wyjścia, ową wspomnianą już matrycą tożsamości” (Melosik, Szkudlarek, 2009, s. 47). Czasy przeszłe zakładały, że tożsamość kulturowa jednostki, aby mogła być skonstruowana, powinna odwołać się do jakiejś matrycy, czasy obecne zakładają bezpośrednią relację jednostki do kultury bez pośrednictwa takiej matrycy. Mechanika procesu kreowania tożsamości jest zupełnie inna. Można by, jako argument dla powyższej tezy, przywołać prace Z. Baumana i jego koncepcję czterech typów relacji jednostek do kultury, a więc konstruowania tożsamości kulturowej jednostek (Bauman,1998). W czasach globalizacji odwoływanie się do tożsamości kulturowej rozumianej monumentalnie będzie skazane na porażkę. Tożsamość kulturowa nie jest nieruchomym historycznym cokołem, do którego się odwołujemy, ale „żywą matrycą, na bazie której stale powstają wyobrażenia i wierzenia ukierunkowane przez oś narodzin” - jak pisze Delsol (Delsol, 2018, s. 29). Tożsamość traktuje jak matrycę, która rodzi istoty wciąż nowe, ale zawsze według tego samego podstawowego wzoru. Delsol stawia tezę, że „potrzebujemy dzisiaj wymyślić coś nowego na bazie tej matrycy. Można mówić o pewnej architekturze myślowej czy o fałdzie myśli, które w każdej epoce odnajdujemy te same, chociaż za każdym razem inne” (Delsol, s. 20).

\section{PRZEKAZ PEDAGOGICZNY W KONTEKŚCIE STANDARDU WIELOKULTUROWOŚCI}

Teoretyczną perspektywę dla analiz i konstruowania przekazu pedagogicznego w perspektywie standardu wielokulturowości daje nam koncepcja Jamesa W. Careya: rytualna koncepcja komunikacji. Komunikacja znajduje się w związku z kontekstem i jest to związek podwójny: komunikacja konstytuuje rzeczywistość oraz komunikacja komentuje rzeczywistość. Pierwszy związek odwzorowuje doświadczenie uwikłania jednostki w kulturę, kiedy drugi związek odsłania moc jednostki w stosunku do kultury. Metodologicznie, komunikację analizujemy poprzez jej przedmiot: symbol komunikacyjny. To symbole mają moc konstytuującą rzeczywistość, pod warunkiem jednak, że są one strukturalnie uporządkowane oraz istnieje struktura ich użycia. Stabilizacja strukturalna symbolu opiera się na 
roli znaczenia i podtrzymywania ciągłości społecznej, stąd horyzontem prawdziwości staje się uczestnictwo i kultura - rozumiana tutaj jako społeczna sytuacja przejmowania, powielania, używania symbolu (zob. Carey, 1989). Tym samym komunikacja przybiera formę rytuału. Rytuał w studiach Careya jest interpretowany za Arnoldem van Gennepem, który poświęcił temu pojęciu pracę pt. Obrzędy przejścia. W pracy tej Autor analizuje funkcjonalność społeczną rytuału:

„Zarzucanie rytuałowi 'bezduszności' czy 'pustego formalizmu’ wynika z niezrozumienia jego istoty, którą jak na ironię dość precyzyjnie wychwytuje sam zarzut wysunięty wobec rytuału. Co mamy na myśli, gdy ów scenariusz powtarzalnych zachowań, podporządkowanych niejasnej dla obserwatora celowości, nazywamy 'pustym'? Czy nie stwierdzamy w ten sposób naszego oddalenia od świata, który rozumiał go bez słów? Czy zatem określenie 'pusty’ istotnie odnosi się do jakiejś wady rytuału, czy raczej do nas samych, z naszym brakiem wiedzy o nim i z naszym rozczarowaniem w zetknięciu z jego całkowicie nieromantyczną egzoteryką? Mówimy o nim 'pusty’, 'mechaniczny’, jak gdyby normę działania religijnego stanowiło intensywne przeżycie religijne, pozwalające wszakże ta sprzeczność wcale nas nie zraża - zachować intelektualna kontrolę nad jego przebiegiem. Oczekując od rytuału, że będzie ‘żywy’, zajmujący i w pełni dla nas zrozumiały, zachowujemy się jak nieodrodni synowie i córki cywilizacji rozrywki... Rytuał musi być pusty właśnie po to, by wykonywał swoje zadanie, aby grupa lub pojedynczy człowiek mogli wpisać się weń i wykorzystać go jako pojazd kontrolowanej zmiany” (van Gannep, 1981, s. 15).

Jak pisze Eric W. Rothenbuhler, interpretując rozumienie komunikowania przez pojęcie rytuału: „wiąże się ona wówczas bardziej z przedstawieniem niż ruchem, uczestnictwem niż konsumpcją, ze znaczeniem lub pięknem niż strategią lub rezultatem, ewokacją lub wyzwaniem niż wpływem lub skutecznością. Rytuał nie jest przeznaczony do oglądania, lecz do uczestniczenia w nim. Podobnie nie jest czymś, co się może komuś zdarzyć, lecz czymś co się wybiera, aby stać się jego częścią” (Rothenbuhler, 2003, s. 154). W konkluzji: „Na istotę rytuału, podobnie jak na każdą inna formę komunikacji, składają się: połączenie idei oraz form materialnych ekspresji, interpretacje jednostkowe oraz wspólne struktury języków, symboli i znaczeń, szczególne cechy sytuacji komunikacyjnej oraz uniwersalia tradycji i kultury” (Rothenbuhler, 2003, s. 79). Należy podkreślić, że proponowane podejście zwraca naszą uwagę na znaczenie zjawiska (które obserwujemy, opisujemy, uczestniczymy), a nie na efekt, jaki wywołuje to zjawisko. Przedmiotem teorii rytualnej koncepcji komunikacji jest więc przekaz jako zjawisko, które „działa” na umysł człowieka, a nie na zjawisko, które „powoduje”, że ludzki umysł reaguje. Rytualna koncepcja komunikacji podkreśla też wspólnotowość, 
ład i trwałość jako cechy komunikacji, moderujące interpretacje rzeczywistości w umysłach ludzi. W sytuacji wspólnoty, struktury społecznej trwałej i uporządkowanej statusowo, przekaz jest jednoznacznie interpretowany przez jednostki, niepoddawany refleksji, a tym samym zaczyna działać totalnie - definiuje nasze postrzeganie świata oraz usztywnia naszą tożsamość. Gdy wspólnota nie jest oparta o silną strukturę statusową, ład i porządek symboliczny jest rozproszony, przekaz traci swoją moc totalną. Jednostki różnie interpretują przekaz. Ten mechanizm komunikacyjny leży u podłoża zgeneralizowanych postaw wobec świata: etnocentrycznej lub etnorelatywistycznej. W perspektywie standardu wielokulturowości etnocentryzm jako zgeneralizowana postawa wobec świata wyostrza różnicę kulturową, nadając jej często zbyt wielką wagę i blokuje pracę w kierunku poszukiwania obszarów wspólnych; relatywizm kulturowy natomiast jako zgeneralizowana postawa redukuje znaczenie różnicy kulturowej, powoduje, że jednostki w procesie interpretacji odwołują się do różnorodnych perspektyw ideologicznych, wprowadzając swoiste zamieszanie w strukturach. Wykraczają poza tradycję, która jest strażnikiem i gwarantem trwałości struktury. Znaczenie symboli bowiem regulowane jest właśnie tradycją [grupy, epoki itp.]. Symbol ma moc stwarzania rzeczywistości w jej wartościującym sensie, to znaczy, że jeśli symbol „mówi”, to opowiada rzeczywistość w układzie struktury, do której dany symbol należy - jest czytelny o tyle, o ile zrozumiemy sugerowane symbolem granice jego czytania. Tradycja to ekosystem kultury - jak przekonuje nas Delsol, kiedy prowadzi analizę potrzeby spójności systemu przekonań, zachowań, sposobów bycia, nawyków i wreszcie zwyczajów. Tradycja wprowadza układ (jakiejś) kultury w sferę ducha i moralności. Artefakty kulturowe dzięki tradycji właśnie osiągają wagę symbolu i są źródłem wiedzy orientującej jednostki wartościująco, a nie tylko opisowo. Trening do komunikacji w standardzie wielokulturowym powinien zakładać kształcenie poznawcze w zakresie treści kulturowych artefaktów, wyrazicieli nastawień i motywów zbiorowych grup i zbiorowości. Warstwa uświęcenia zwykłej interakcji jest zatem systemem form symbolicznych, który służy rytualnemu tworzeniu sfer uporządkowanych w perspektywie moralności (Rothenbuhler, s. 137). Artefakty kulturowe (w klasie artefaktów materialnych, behawioralnych i wyrażeń) konstruowane są wedle określonych (ukrytych) reguł, które określają porządek rytualny, są wysoce uwzorowane, choć niewielu potrafi je sformułować (Rothenbuhler, s. 96). Wpisane są w rzeczywistość społeczną. Świadoma decyzja jednostek, w tym układzie, w nowych warunkach kulturowych, odnosi się tym samym do świadomości jednostek, owego procesu wpisywania wartości w krąg działań i aktywności jednostki. 


\section{KOMPETENCJE JEDNOSTEK DO KOMUNIKACJI W STANDARDZIE WIELOKULTUROWYM}

„Przeświadczenie, że świat człowieka jest intersubiektywnym światem kultury, gdyż żyjemy w nim jako ludzie wśród innych ludzi, związani z nimi poprzez wzajemne oddziaływanie i pracę, rozumiejąc innych i będąc przez nich rozumiani, prowadzi do przekonania, iż świat człowieka ma postać narracji. Jest uniwersum znaczeń, czyli sensownych struktur, które musimy stale interpretować, i sensownych odniesień, które ustanawiamy w tym świecie dopiero dzięki naszym działaniom. Interpretacja ta polega na ciągłym odczytywaniu zdarzeń, sytuacji oraz własnego i cudzego losu. Rozumiemy to, co się z nami i innymi dzieje właśnie w postaci odczytywanych przez nas opowieści, docierających do nas narracji” (Nowak-Dziemianowicz, 2011, s. 38). Taką tezę sformułowała Mirosława Nowak-Dziemianowicz w swojej pracy: Narracja - Tozsamoś - Wychowanie. Perspektywa przejścia i zmiany. Powołując się na nią jako na swoiste motto wyznaczające problemy związane z kompetencją komunikacyjną jednostek w standardzie wielokulturowości, należałoby zapytać o moc interpretacyjną jednostek, sensowność interpretacji oraz o prawomocność narracji. Komunikowanie jest czynnością osadzoną w świecie społecznym i zapośredniczoną symbolami. Moc interpretacyjna jednostek odnosi nas tym samym do pytania o prawomocność interpretacji jednostkowych. Jak twierdzi Rothenbuhler: „niewielu wciąż tkwi w błędzie, uważając, że nie tyle rzeczywistość jest ukształtowana na sposób symboliczny, co każda jednostka może stworzyć sobie taką rzeczywistość, jaką chce. Moc stwórcza symboli pozostaje - logicznie rzecz biorąc - w ludzkich rękach, nie oznacza to wszakże, iż pozostaje ona w rękach jednostki. Rzeczywistość kształtowana symbolicznie stanowi w równym stopniu część środowiska, które musi przyjąć jednostka, co rzeczywistość fizyczna. Nasze języki, kultury, tradycje, role społeczne itd. zostały nam przydane; jesteśmy w tej krainie mieszkańcami, a nie jej twórcami, (Rothenbuhler, 2003, s. 78). Podobnie, choć w odmiennej perspektywie narracyjnej, o mocy symbolizacyjnej jednostek wypowiada się Delsol: „Indywidualizm jest złudzeniem. Nie można wyobrazić sobie społeczeństwa, w którym każdy sam z siebie przestrzega reguł moralnych, nie będąc do tego w taki czy inny sposób skłaniany. Może to zrobić tylko elita mędrców (nie elita intelektualna, bo to co innego). Zwyczajna i pospolita moralność, czyli granice narzucone woli jednostki, kształtuje się pod wpływem presji społecznej, która może zależeć od religii lub władzy” (Delsol, 2018, s. 84). Autorka dostrzega jednak także przestrzeń na relacje odwrotne, kiedy to wola jednostki, jej autorska interpretacja artefaktu kultury, zostaje przechwycona i pochłonięta przez powszechną opinię, stając się 
powszechnie obowiązującym standardem interpretacji artefaktu kultury. (Delsol, 2018, s. 59). Niemniej znaczący artefakt kultury zawsze odnosi się do zbiorowego umysłu i tylko wtedy, kiedy interpretacja zostanie zaktualizowana społecznie taki symbol przenosi intencje i wartości, inaczej mówiąc, nie jest tylko tym, czym jest. Wybory jednostek komunikowane poprzez artefakty kultury: materialne, np. decyzja o wyborze ubioru, który komunikuje status, zachowania, poprzez wybrane formy czy wybór nazw lub określeń, są efektem uwikłania jednostki w rzeczywistość - standardu moralnego i jego realizacji w układzie społecznym, gdzie jednostka, aby zakomunikować wartościowość „odbija się” o tło społeczne: mentalność, statusowość. Jednostka jest komunikatywna pod warunkiem podzielania komunikacji ze swoim rozmówcą. W przypadku standardu wielokulturowości nie ma takiej przestrzeni (określonej), brak jest kanonu, a co za tym idzie, brak jest struktury, która by wspierała i uprawomocniała ów kanon. Owa nieokreśloność, nieoznaczalność kanonu i związana z tym sytuacja napięcia, niepewności powoduje, że poszukujemy rozwiązań tego stanu rzeczy. W zakresie kompetencji komunikacyjnej badacze problemu proponują zmianę paradygmatu interpretacyjnego. Mirosław Sobecki swojej książce: Komunikacja międzykulturowa w perspektywie pedagogicznej zaproponował pojęcie symbiozy kulturowej, które uprawomocnia włączanie elementów obcych tradycji w krąg naszej i wartościuje pozytywnie to zapożyczenie. Dowartościowanie zapożyczenia otwiera nas na konstruowanie komunikacji standardu wielokulturowości. W tym układzie zapożyczenia, włączane w krąg znaczeniowy naszej tożsamości, pozostają w naszej świadomości elementem także innej odmiennej kultury, nie są przejmowane i zawłaszczane (zob. Sobecki, 2016, s. 195-199). Narracją edukacyjną w tym układzie powinny być dzieje przenikania, włączania danego artefaktu kultury, a nie procesy dokumentujące „korzenność” danego artefaktu w naszej tradycji. Wyzwaniem w zakresie komunikacji standardu wielokulturowości jest też zagadnienie tradycji. Jako że postmodernizm czy późna nowoczesność oprotestowuje kanony i tradycje z definicji, to problematyczne staje się komunikowanie skomplikowanych idei, postaw, światopoglądów. Brak jest bowiem wspólnej przestrzeni tradycji dla wyrażania i odbierania tych wrażliwych na wartościowanie informacji. Mówiąc o komunikacji standardu wielokulturowości w zakresie transformacji tradycji, pewnym tropem dla rozważań w pedagogice wydaje się być rozwijanie postawy otwartej. Narracja edukacyjna powinna koncentrować się nie na wprowadzaniu wychowanka w symbole naszej tradycji, a budowanie aparatu poznawczego pozwalającego jednostkom na uprawnione porównania, analogie między tradycjami. Dzisiaj w ponowoczesnej rzeczywistości złożonego świata, za badaczką problemu, Marthą C. Nussbaum, można by powtórzyć, że wyżej wymienione sprawności poznawcze powinny 
być osadzone w duchu etycznej filozofii Sokratesa, wyłożone przez nią w trzech punktach: „(1) - zasady polityczne wyrażające równy szacunek dla wszystkich obywateli oraz zrozumienie tego, czego zasady te wymagają, jeśli weźmie się pod uwagę obecne zróżnicowanie religijne [kulturowe], (2) - rygorystyczne, krytyczne myślenie, które wynajduje, krytykuje sprzeczności, zwłaszcza jeśli polegają one na czynieniu wyjątku dla samego siebie i zauważaniu „źdźbła” w czyimś oku, gdy samemu ma się na nich klapki, (3) - systematyczne ćwiczenie „wewnętrznych oczu”, zdolności do posługiwania się wyobraźnią, co sprawia, że możliwe staje się oglądanie świata z punktu widzenia osoby o odmiennej religii lub pochodzącej z innej grupy etnicznej” (Nussbaum, 2018, s. 22).

Kolejną perspektywą budującą kompetencje komunikacyjne w standardzie wielokulturowości jest racjonalność jako wartość, na której budujemy indywidualne interpretacje, odczytujemy kulturę Innych, oraz odpowiedzialność jako wartość, na której budujemy relację z Innym. Jak szeroki i wywołujący wielość dylematów jest to problem, przedstawił w swoim wystąpieniu na forum IV Kongresu Polskich Towarzystw Naukowych na Obczyźnie Jerzy Nikitorowicz. Podkreśla on hybrydalność jako immanentną cechę współcześnie kreowanych symboli kulturowych, które w przełożeniu na narracje tożsamościowe wywołują ludzkie problemy ryzyka, wolności wyboru i odpowiedzialności za ten wybór (Nikitorowicz, 2014). Wartość racjonalizmu i racjonalność jako postawa to fundamenty kultury europejskiej, na tym opiera się europejska edukacja. „W Europie kształci się inicjatywę, tutaj to zapoczątkowano, podczas gdy w innych społeczeństwach trwa edukacja inicjacyjna. Inicjacja oznacza, że pewien korpus wiedzy i praktycznych umiejętności zostaje przekazany jednostce w odpowiednim wieku po to, aby je odtwarzała. Inicjowany niczego nie podważa, w przeciwnym razie wypadłby z systemu. Kształcenie inicjatywy natomiast prowadzi do powstania podmiotów, które uczą się władać pewnym zasobem wiedzy i go krytykować. (...) ale jego [edukacji] naczelnym celem ważniejszym niż dostarczenie konkretnej wiedzy jest nauka samodzielnego myślenia” (Delsol, 2018, s. 98). Dalej precyzując ideę racjonalizmu, Autorka, powołując się na treść dzieła z XIX w. o istocie uniwersytetu, podaje: „otwarcie umysłu, korygowanie jego działania, oczyszczanie go i jakby wygładzanie, danie mu możności poznania, a potem przyswojenia nabytej wiedzy, panowania nad nią, rządzenia nią i używania jej, uzdolnienie go do kierowania własnymi władzami, rozwiniecie pilności, giętkości, metodyczności, dokładności krytycznej, rozumnej i wnikliwej oceny spraw, gotowości do działania, zręczności, elokwencji i ekspresji” (Newman, 1990, s. 200-201), racjonalność bowiem winna zarządzać interpretacją artefaktów kultury, a nie, jak nazywa go Autorka, „bezczelny humanizm, rozszalały antropocentryzm, hulający indywidualizm” (zob. Delsol, 2018, 
s. 83). Podobnie wypowiada się pedagog Wolfgang Brezinka. Konstatuje on, że indywidualistyczna demokracja prowokuje chaos kulturowy. „Zawiera on w sobie przeróżne tradycje, które do siebie nie pasują: religijne i ateistyczne, ukierunkowane na prace i przyjemność, elitarne i egalitarne, regionalne i narodowe lub ponadnarodowe itp. Wiele z nich wyklucza się nawzajem, wszystkie do siebie werbują, wszystkie zmieniają się pod wpływem ducha czasu” (Brezinka, 2005, s. 11). Drogę wyjścia widzi Delsol, w aktywnej postawie człowieka wobec własnego świata. „Wyjście z nihilizmu polega po prostu na określeniu, jaka przyszłość jest godna szacunku. Wymaga to obrony spójnego świata, to znaczy świata, który nie zdaje się $\mathrm{z}$ dnia na dzień na pragnienie jednostek. Trzeba zrozumieć, że od około dwóch wieków żyjemy w świecie fikcyjnym w tym sensie, że wszystko co nas otacza, uważane jest za pozbawione wartości, bo czekamy na coś lepszego, co również szybko porzucamy” (Delsol, 2018, s. 26). Trudno zaprzeczyć, że zjawisko różnorodności kulturowej wywołuje ten obraz. Reagowanie na ten stan zamknięciem się do kręgu własnej tradycji będzie rodzić niezrozumienie, obawy, bojaźń w stosunku do obcych, a w efekcie konflikty zbrojne. Postawa otwartości powinna mieć jednak granice racjonalności. Warto w tym kontekście odwołać się do teorii działania komunikacyjnego Jurgena Habermasa, odczytania której podjęła się Anna Michalska. Twierdzi ona, że bazując na założeniu o tym, że wiedza naukowa jest gwarantem i probierzem racjonalności, wnosi ono nową jakość w interpretacji pojęcia. Wprowadza bowiem do debaty na temat racjonalności nowe elementy nieasymilowane w klasycznej teorii nauki. W teorii działania komunikacyjnego racjonalność jako pojęcie ma szerszy zakres znaczeniowy, a warunki racjonalnego działania są zarazem warunkami poznania. Poza tym na gruncie tej teorii można też opisać i wyjaśnić czynniki zaburzające racjonalność (Michalska, 2015, s. 224). Zasadniczo racjonalność jako postawa poznawcza ufundowana jest na trzech filarach poznania: obiektywnego, społecznego i subiektywnego. Obiektywny aspekt oznacza analizę przyczynową zjawisk czy przedmiotów, filar społeczny to analiza uznawanych zasad wyższego rzędu, które określają kontekst normatywny. Prawomocność norm uprawomocnia się w postawach komunikujących, a ich efektywność zależy od tego, jak głęboko są zinternalizowane przez uczestników komunikacji. Filar subiektywny to aspekt odpowiadający za wyrażane indywidualnie postawy uczestników komunikacji. Subiektywność rozumiana mentalistycznie, ograniczona do życia wewnętrznego jednostki na gruncie tej teorii, jest rozpatrywana jako symptom zaburzeń komunikacyjnych. Owe filary racjonalności należy rozumieć jako odrębne porządki analizy i jako zasadę niemylenia ze sobą różnych porządków myślenia i działania (zob. Michalska, 2015, s. 228). 
Odpowiedzialność jako wartość organizująca nasze relacje z Innym przede wszystkim odnosi się do naszej tożsamości kulturowej (jednostkowej). Tylko w sytuacji, gdy swoje ,ja” kulturowe odnosimy do jakiejś zbiorowości, zakorzeniamy się w tradycji jakiejś grupy, możemy racjonalnie omawiać zagadnienie praw i obowiązków. Osoba ma prawa, ponieważ żyje w pewnym środowisku i tylko pod warunkiem odniesień do tego środowiska buduje świat odpowiedzialności. Innym problemem jest, że współczesne „ja” kulturowe bywają synkretyczne. Trudno nieraz jednostkom określić odniesienia do grup i tradycji. Jest to problem, a nie zasada. Stąd prawa człowieka i granice jego odpowiedzialności definiowane jako: rób co chcesz, pod warunkiem, że nie naruszasz wolności drugiego - co jest popularną interpretacją odpowiedzialności w świecie zglobalizowanym - jest to jednak niewystarczające, bo społeczeństwo, w którego łonie powstają i są realizowane prawa i obowiązki jednostek, nie są zbieraniną izolowanych jednostek z ich własną wolnością, ale raczej obrazem relacji grupowych. Jak analizuje Delsol: „chodzi nie tylko o szanowanie wolności drugiej jednostki, ale również o respektowanie tożsamości grupowej” (Delsol, 2018, s. 113). Być odpowiedzialnym oznacza tym samym świadomość własnej jednostkowej zależności od grupy w sensie swoich praw i obowiązków. Odpowiedzialność jest obowiązkiem, nie prawem. „Poznać i uznać porządek świata, do którego jesteśmy przypisani - oto cena, za jaką możemy być odpowiedzialni” (Delsol, 2018, s. 111). Oznaczałoby to obszar relacji jednostki z jej własną tradycją, świadome i rozumne procesy dziedziczenia, kiedy odnosząc się do artefaktów w kulturze jednostka odpowiedzialnie i rozumnie wpisuje je w swoją tożsamość. Pedagog Wolfgang Brezinka także podnosi temat odpowiedzialności, robi to w kontekście procesu wychowania. Analizując problem podkreśla, że w procesie wychowania, który jest celowy, ważne jest, aby realizowany cel odnosił się realiów świata jednostek. Jak podkreśla, wychowanie winno być autentyczne (Brezinka, 2005, s. 78). Następnie uważa on za ważne, że „(...) ta ceniona kultura ekonomiczno-techniczna musi opierać się na etycznych fundamentach i wymaga moralnej kontroli” (Brezinka, 2005, s. 80). Cytatem tym podkreśla, że materialny porządek kultury (w innych tekstach nazywany cywilizacyjnym) idzie w parze z porządkiem moralnym, którym powinniśmy zarządzać tak, aby oba porządki były spójne. Widzi ową moralną kontrolę poprzez procesy wewnętrzne i zewnętrzne. Procesy wewnętrzne to orientacja zbiorowości ludzkich na pewne wartości, specyficzne dla każdej z grup kulturowych systematyki wartościowania, często zależnej od relacji międzygrupowych, dziedzictwa kultury, statusu społecznego. Ośrodki informacji i kontroli, budując etykę, znajdziemy w artefaktach kultury symbolicznych dla grupy. Druga (zewnętrzna) to określana przez Brezinkę pojęciem kultury normatywnej, będąca swoistym standardem 
społecznym w zakresie kultury, ujawnianym w toku zachowań codziennych, wyborach i decyzjach. Jak twierdzi: „osobista kultura jednostki zależy w dużej mierze od poziomu zewnętrznej ponadindywidualnej kultury grupy, do której jednostka należy” (Brezinka, 2005, s. 81).

\section{PODSUMOWANIE}

W podsumowaniu rozważań o komunikacji standardu wielokulturowego należy podkreślić, że sama materia problemu jest proweniencji ideologicznej. O komunikacji standardu wielokulturowego jako zasadzie społecznej (i celu wychowania) można by realnie mówić w układzie społeczeństwa, które przyjmie idee wielokulturowości. Przesłanki do tego pojawią się, kiedy oczywistością i naturalnym stanem rzeczy będzie pluralizm kulturowy oraz wytworzy się trzecia przestrzeń kultury, spajającej ów stan pluralizmu kulturowego w koherentny układ wartościowania, pozwalający jednostkom na konstruowanie orientacji życiowych raczej włączających, spajających i budujących ciągłość społeczną, niż wykluczających, kategoryzujących, wyznaczających strukturę społeczną mniejszości i większości.

W perspektywie tożsamości zbiorowych musimy liczyć się ze zmianą symboli komunikacyjnych, budową nowych układów, ciągów znaczeniowych, przewartościowań w zakresie symboliki zachowań, odniesień do artefaktów czy intencji kodowanych w języku. Grupy kulturowe staną się niejednorodne, a tożsamościowy obraz będzie oscylował w kierunku hybrydalnych form. Relacje jednostkowe wyznaczane będą bardziej wolą jednostek niż uświęconą tradycją grup i zbiorowości. Relacja jednostka a jej tło kulturowe, możemy się spodziewać, będzie bardziej mglista niż wyraźna; bardziej niejednoznaczna niż wyznaczona.

Taki stan rzeczy wymaga zajęcia aktywnej reakcji pedagogów i podjęcia próby konstruowania komunikacji adekwatnej do tego stanu.

Kompetencje komunikacyjne standardu wielokulturowości wymagają rozwijania sprawności poznawczych w zakresie czytania i interpretowania artefaktów kulturowych w realiach wielokulturowych. Niewystarczające jest w tym układzie odnoszenie ich do tradycji naszej, potrzebujemy umiejętności porównań, szukania sensu wspólnego pomimo różnicy tradycji. Potrzebujemy także zasad organizujących ten proces poznawczy, a więc ustalenia etyki owych porównań i wyznaczników interpretacyjnych. Propozycją w tym układzie stają się koncepcja symbiozy kulturowej czy teoria działania komunikacyjnego Jurgena Habermasa.

Wreszcie, mówiąc o kompetencjach do komunikacji standardu wielokulturowości, należy podkreślić istotność wartości i wagę postaw racjonalności i odpowie- 
dzialności, które w układzie kompetencji zajmują funkcje sprawności. Poszukując relacji i związków miedzy tymi wartościami, racjonalność jako postawę można definiować jako konstrukt otwarty, realizujący się tylko w granicach określonych kontekstów, nigdy raz na zawsze i w każdych warunkach. Racjonalność jako postawa rozumna pojawi się pod warunkiem zakorzenienia jej w bazowej otwartości. Otwartość bowiem pozwoli na kreowanie rozumne nowych rozwiązań interpretacji rzeczywistości społecznej. Odpowiedzialna postawa racjonalności w narracji tożsamościowej operuje obrazem, nie modelem, co pozwala unikać krzywdzących kategoryzacji, uwrażliwi na destruktywne działanie stereotypu. W końcu, mówiąc o związku czy relacji odpowiedzialności i racjonalności, uzyskamy efekt zachowania powściągliwości w formułowaniu sądów i ocen jednoznacznych i ostatecznych, czyli standardem stanie się unikanie roszczenia poznawczego. Uwagę w relacjach międzykulturowych skierujemy raczej na szacunek wobec faktów, zaś w mniejszym stopniu wobec zakorzenionego w tradycjach porządku czy procedur istniejących w społeczeństwach.

To właśnie na skutek zastosowania aktywnie przez jednostki tych postaw ustalić się może standard komunikacyjny, który zrealizowany zostanie w ramach rytualnej koncepcji komunikacji w przekazie pedagogicznym.

\section{Bibliografia}

Bauman, Z. (1998). Prawodawcy i tłumacze. Tłum. A. Ceynowa, J. Giebułtowski. Warszawa: Wydawnictwo Instytutu Filozofii i Socjologii PAN.

Brezinka, W. (2005). Wychowanie i Pedagogika w dobie przemian kulturowych. Kraków: Wydawnictwo WAM.

Brozi, K.J. (1994). Antropologia wartości. Kategoria standardu kulturowego w badaniach nad wartościami. Lublin: Wydawnictwo Uniwersytetu Marii Curie-Skłodowskiej.

Carey, J. (1989). Communication as Culture. Boston: Unwin Hyman.

Delsol, Ch. (2018). Kamienie węgielne. Na czym nam zależy? Tłum. M. Kowalska. Kraków: Wydawnictwo Znak.

Gennep, van A. (2006). Obrzędy przejścia. Tłum. B. Biały. Warszawa: Państwowy Instytut Wydawniczy.

Grabowska, B. (2013). Poczucie tożsamości młodzieży uczq̨cej się w szkołach z polskim językiem nauczania na Białorusi, Ukrainie i w Republice Czeskiej - studium porównawcze. Toruń: Wydawnictwo Adam Marszałek.

Kempny, M., Kapciak, A., Łodziński, S. (1997). U progu wielokulturowości. Nowe oblicza społeczeństwa polskiego. Warszawa: Oficyna Naukowa.

Kurczewska, J. (2000). Kanon kultury narodowej. W: Kultura narodowa i polityka. Warszawa: Oficyna Naukowa. 
Linton, R. (2000). Kulturowe podstawy osobowości. Warszawa: Wydawnictwo Naukowe PWN.

Machaj, I. (2005). Społeczno-kulturowe konteksty tożsamości mieszkańców wschodniego i zachodniego pogranicza Polski. Warszawa: Wydawnictwo Naukowe „Scholar”.

Melosik, Z. (2012). Tożsamości w społeczeństwie współczesnym: pop-kulturowe (re)interpretacje. Kraków: Oficyna Wydawnicza „Impuls”.

Melosik, Z., Szkudlarek, T. (2009). Kultura, tożsamość i edukacja - migotanie znaczeń. Kraków: Oficyna Wydawnicza „Impuls”.

Misiejuk, D. (2013). Dziedzictwo i dziedziczenie w kontekście procesów socjalizacji. Białystok: Wydawnictwo Uniwersyteckie Trans Humana.

Misiejuk, D. (2017). Inność w kontekście imigracji - ogląd światopoglądu studentów. Studium interpretacyjne w świetle teorii standardu kulturowego K.J. Brozi. Multicultural Studies, 2.

Nikitorowicz, J. (2009). Edukacja regionalna i międzykulturowa. Warszawa: Wydawnictwa Akademickie i Profesjonalne.

Nowak-Dziemianowicz, M. (2011). Narracja - Tożsamość - Wychowanie. Prespektywa przejścia i zmiany. Teraźniejszość - Człowiek - Edukacja, 3 (55).

Nowicka, E. (2000). Świat człowieka, świat kultury. Warszawa: Wydawnictwo Naukowe PWN.

Nussbaum, M.C. (2018). Nowa nietolerancja religijna. Przezwyciężyć politykę strachu w niespokojnych czasach. Tłum. S. Szymański. Warszawa: Fundacja Kultura Liberalna.

Paleczny, T. (2008). Socjologia tożsamości. Kraków: Oficyna Wydawnicza AFM.

Radomski, A. Antropologia jako nauka. Krzysztofa Broziego koncepcja standardu kulturowego w badaniach kulturoznawczych. https://depot.ceon.pl.

Rothenbuhler, E.W. (2003). Komunikacja rytualna. Od rozmowy codziennej do ceremonii medialnej. Tłum. J. Barański. Kraków: Wydawnictwo Uniwersytetu Jagiellońskiego.

Sadowski, A. (2016). Wielokulturowość jako czynnik zrównoważonego i inteligentnego rozwoju Polski. Optimum Studia Ekonomiczne, 4 (82).

Sadowski, A. (2012). Od eksplozji do realnych zagrożeń idei i praktyk wielokulturowości: potrzeba nowych koncepcji i badań. W:Biernacka M., Krzysztofik K., Sadowski A. (red.). Społeczeństwo wielokulturowe nowe wyzwania i zagrożenia. Białystok: Wydawnictwo Uniwersyteckie Trans Humana.

Sobecki, M. (2007). Kultura symboliczna a tożsamość. Białystok: Wydawnictwo Uniwersyteckie Trans Humana.

Sobecki, M. (2016). Komunikacja międzykulturowa w perspektywie pedagogicznej. Studium z pogranicza polsko-litewsko-białorusko-ukraińskiego. Warszawa: Wydawnictwo Akademickie „Żak”.

Szczurek-Boruta, A. (2007). Zadania rozwojowe młodzieży i edukacyjne warunki ich wypełniania w środowiskach zróżnicowanych kulturowo i gospodarczo. Katowice: Wydawnictwo Uniwersytetu Śląskiego. 